\title{
Quantification of Immunoglobulin G against Trypanosoma cruzi in Individuals with Chronic Chagas Disease Treated with Nifurtimox and Evaluated in Prolonged Follow-Up
}

\author{
Gabriela Muñoz, Camilo Vergara, Gabriela Martínez, Werner Apt, Inés Zulantay* \\ Laboratory of Basic-Clinical Parasitology, Program of Cellular and Molecular Biology, Institute of Biomedical Sciences, Faculty of Medicine, \\ University of Chile, Santiago, Chile
}

\begin{abstract}
In the indeterminate chronic period of Chagas disease $(\mathrm{ChD})$ the treatment has not been conclusive, because the serological negativization requires many years. This study aims to evaluate the efficacy of nifurtimox (NF) in the treatment of chronic ChD in prolonged follow-up by serological techniques of indirect immunofluorescence assay (IFA) and enzyme-linked immunosorbent assay (ELISA) IgG comparing 2 groups of patients, treated and non treated. Mann-Whitney test was performed for ELISA and IFA, with significant difference between the groups $(P<0.05)$. IgG levels were lower in individuals treated compared with untreated patients, indicating chemotherapeutic efficacy in prolonged follow-up.
\end{abstract}

Key words: IFA, ELISA, chronic Chagas disease, IgG, nifurtimox, follow-up

Chagas Disease or American Trypanosomiasis is a vectorborne parasitic zoonosis caused by Trypanosoma cruzi and transmitted by triatomine insects, mainly by Triatoma infestans. Other non-vector mechanisms of transmission are the congenital and blood transfusion, which are the main infection routes in urban areas and non-endemic countries [1-3].

The World Health Organization (WHO) estimates that around 7 million people are infected worldwide [4]. ChD has 2 clinical stages that influence the choice of the diagnostic method: an acute phase and a chronic phase $[2,3,5]$. Patients remain chronically infected after the acute phase; $60-70 \%$ people will never develop symptoms, which is called the indeterminate form of the chronic phase of the disease. The remaining patients with chronic Chagas disease will develop cardiomyopathy or megavisceras, usually 10 to 30 years after primary infection $[2,3,5]$. While in the acute phase diagnostic methods are focused on finding T. cruzi in blood samples by direct parasitological methods, diagnosis in the chronic stage is mainly made by serological tests like enzyme-linked immunosorbent assay (ELISA), immunofluorescence assay (IFA) and indirect

- Received 23 October 2018, revised 22 January 2019, accepted 22 January 2019.

*Corresponding author (izulanta@med.uchile.cl)

(c) 2019, Korean Society for Parasitology and Tropical Medicine

This is an Open Access article distributed under the terms of the Creative Commons Attribution Non-Commercial License (http://creativecommons.org/licenses/by-nc/4.0) which permits unrestricted non-commercial use, distribution, and reproduction in any medium, provided the original work is properly cited. hemagglutination (IHA) [2]. The only currently authorized drugs for Chagas disease treatment are benznidazole (BZ) and nifurtimox (NF), both with frequent incidence of side effects, and uncertain and variable efficacy [5-7]. The conventional cure criterion for the chronic phase of $\mathrm{ChD}$ is the negativization of at least 2 serological tests, but results of serological studies on the evolution of treated chronically infected patients has been discordant [8]. This study aims to evaluate if there are statistically significant differences between IgG antibody levels against T. cruzi using IFA and ELISA IgG tests in patients with chronic Chagas disease treated and not treated with $\mathrm{NF}$, evaluated in prolonged follow-up, to determine the chemotherapeutic efficacy of the drug.

Serum samples of 100 patients with chronic ChD treated with NF from rural and urban Coquimbo Region, Chile, were collected between June and July 2016. All were previously treated on average 6.6 years (Group 1).

Serum samples of 100 patients with chronic ChD not treated, from the same localities of Group 1. All were controlled in their condition of chronic infected. Characterization of patients is shown in Table 1. All patients from Group 1 were treated according to the therapeutic scheme recommended in the current Guide for the Diagnosis, Treatment and Prevention of Chagas Disease [9]. Every patient was enrolled in the study under Informed Consent given in writing, and approved by the Ethics Committee of the Faculty of Medicine of the Uni- 
Table 1. Characterization of 200 treated and untreated of Chile patients with chronic Chagas disease

\begin{tabular}{|c|c|c|c|c|c|c|c|c|c|c|c|}
\hline \multirow{2}{*}{ Group } & \multicolumn{3}{|c|}{$n$} & \multicolumn{3}{|c|}{ Urbanization Area } & \multicolumn{2}{|c|}{ cPCR } & \multicolumn{3}{|c|}{ ECG } \\
\hline & Total & Female & Male & & Rural & Urban & $(+)$ & $(-)$ & Normal & Altered & ND \\
\hline Treated & 100 & 78 & 22 & 49 & 31 & 69 & 19 & $81^{a}$ & 68 & $32^{a}$ & 0 \\
\hline Untreated & 100 & 74 & 26 & 53 & 58 & 42 & 76 & 24 & 40 & 44 & 16 \\
\hline Total & 200 & 152 & 48 & 51 & 89 & 111 & 95 & 105 & 108 & 76 & 16 \\
\hline
\end{tabular}

ND, no data; CPCR, conventional PCR; ECG, conventional electrocardiogram. aPost-therapy condition.

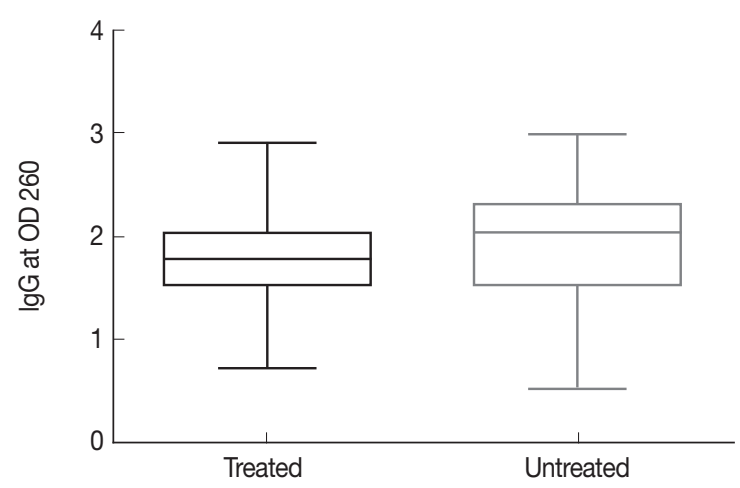

Fig. 1. Serum lgG antibody titer (optical density) measured using ELISA from chronic Chagas disease patients treated or untreated with NF.

versity of Chile (Protocols 048/11 and 012/16). ELISA IgG tests were performed using the ELISA Chagas III kit (GrupoBios, Santiago, Chile). Cutoff was calculated based on optical density (OD) of the negative and positive control plates. Samples were considered positive when the absorbance was greater than the cutoff [10]. IFA was performed using the Tulahuén strain of T. cruzi (in-house). The applied diagnostic titer was $1 / 20$, according to the positivity criteria estimated in Chile [11]. Positive and negative controls were included in all the assays. Data were analyzed in the program STATA v.19. Shapiro Wilk, Levene test and Mann-Whitney test were applied with a significance level of 0.05 .

The results show that 68 cases of Group 2 had OD greater than $1.807 \mathrm{~nm}$, while 68 cases of Group 1 were below that value. The Shapiro-Wilk test found not normal distribution $(P<0.0001)$. Mann-Whitney test showed a significant difference $(P=0.0003)$ between ELISA OD from patients in Group 1 and Group 2 (Fig. 1). 51 patients from Group 2 were in the greatest dilution $(1 / 1,280)$, whereas 25 patients from Group 1 were in that dilution. A single treated patient was negative in the IFA test, in accordance with an ELISA result near the cutoff. The Shapiro-Wilk test was performed and neither group showed a normal distribution $(P<0.0001)$. A significant dif-

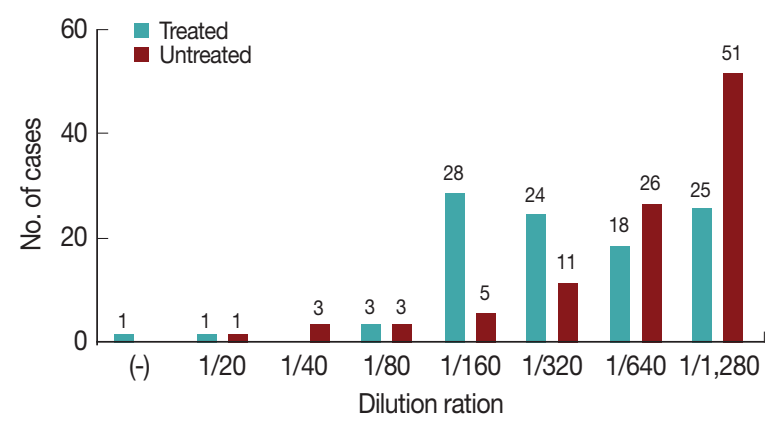

Fig. 2. Distribution of IgG antibody by IFA in patients with chronic Chagas disease.

ference between IgG antibody titters from treated and untreated group was determined by Mann Withney test $(P=2.2$ e-16). Data were grouped according to the titer obtained for each patient in both groups (Fig. 2).

The diagnostic methods in $\mathrm{ChD}$ are determined by the natural progress of infection. In the acute phase, the parasite presence is evident and for this reason, in treated patients the cure is evidenced by negative serological and parasitological tests. In the chronic phase, the parasitemia is usually low and undetectable being the specific IgG anti-T. cruzi antibody detection the method of choice [10]. Follow-up of patients in the chronic phase has shown that antibody titers remain stable if no trypanocidal treatment is received [12]. The establishment of cure criteria in the chronic phase is controversial. Patients evaluated in post-therapy condition can show parasitemia detected by several parasitological methods indicating persistence of the infection and therapeutic failure, while that patients without parasitemia but with positive serology are not considered cure because it remains positive many years after therapy [13]. That is how the seronegativization can occur within 5 years in the acute phase, from 5 to 10 years in a recent chronic phase (up to 10 years from initial infection), and more when the infection has been present for more than 20 years. At respect, experts recommend to save the first serum sample to compare changes in antibody titers every year on the use of 2 different 
serological methods against T. cruzi antigens. As the most used are ELISA and IFA, because sometimes IHA can be negative before treatment [2]. In the present study, 1 case from Group 2 had results near the cutoff in ELISA and IFA. This fact can be explained by a spontaneous seronegativization occurred in 3\% of untreated patients, which may be related to an efficient immune response $[2,14]$. Although this study demonstrate that the IgG levels were lower in individuals with chronic $\mathrm{ChD}$ treated with NF compared to untreated patients, indicating chemotherapeutic efficacy in prolonged follow-up, the need the find new serological markers to evaluate in the follow short-term the chemotherapeutic efficacy in the chronic phase of $\mathrm{ChD}$, is urgent.

\section{ACKNOWLEDGMENTS}

This study was supported financially by Fondecyt Projects 1080445 and 1161485. The authors thank Drs. Juan Diego Maya, Michael Lapier, Gonzalo Cabrera and Lucía Valenzuela (Biomedical Sciences Institute, Faculty of Medicine, University of Chile) for the contribution of Trypanosoma cruzi strains.

\section{CONFLICTS OF INTEREST}

The authors declare that they have no competing interests.

\section{REFERENCES}

1. Toso A, Vial F, Galanti N. Transmisión de la enfermedad de Chagas por vía oral. Rev Méd Chile 2011; 139: 258-266 (in Spanish).

2. Rassi A Jr, Rassi A, Marcondes de Rezende J. American Trypanosomiasis (Chagas disease). Infect Dis Clin North Am 2012; 26: 275-291.

3. Cabello C, Cabello F. Zoonosis con reservorios silvestres: amena- zas a la salud pública y a la economía. Rev Méd Chile 2008; 136: 385-393 (in Spanish).

4. World Health Organization. Chagas disease in Latin America: an epidemiological update based on 2010 estimates. Wkly Epidemiol Rec 2015; 90: 33-44.

5. Pérez-Molina JA, Molina I. Chagas disease. Lancet 2018; 391: $82-$ 94.

6. Apt W, Zulantay I. Estado actual en el tratamiento de la enfermedad de Chagas. Rev Méd Chile 2011; 139: 247-257 (in Spanish).

7. Bern C. Antitrypanosomal therapy for chronic Chagas' disease. N Engl J Med 2011; 364: 2527-2534.

8. Sguassero Y, Cuesta CB, Roberts KN, Hicks E, Comandé D, Ciapponi A, Sosa-Estani S. Course of chronic Trypanosoma cruzi infection after treatment based on parasitological and serological test: a systematic review of follow-up studies. PLoS One 2015; 10: e0139363.

9. Ministerio de Salud. Guía de diagnóstico, tratamiento y prevención de la enfermedad de Chagas. Guías Clínicas 2011 (in Spanish).

10. Flores-Chávez M, Cruz I, Rodríguez M, Nieto J, Franco E, Gárate T, Cañavate C. Comparación de técnicas serológicas convencionales y no convencionales para el diagnóstico de la enfermedad de Chagas importada en España. Enferm Infecc Microbiol Clin 2010; 28: 284-293.

11. Astorga B, Lorca M, Thiermann E. Determinación de la reacción de Inmunofluorescencia indirecta para la enfermedad de Chagas en Chile. Parasitología al Dia 1998; 12: 132-135 (in Spanish).

12. Luquetti A, Rassi A. Perspectiva del uso de la serología (Ag naturales y otros) en la evaluación de la eficacia del tratamiento etiológico. 2nd Simposio Internacional de Enfermedad de Chagas 2002 (in Spanish).

13. Rassi A, Luquetti A. Specific treatment for Trypanosoma cruzi: lack of efficacy of allopurinol in the human chronic phase of Chagas disease. Am J Trop Med Hyg 2007; 76:58-61.

14. Luquetti A, Schmuñis G. Diagnosis of Trypanosoma cruzi infection. In Telleira J, Tibayrenc M, eds, American Trypanosomiasis Chagas Disease. 2nd ed. Amsterdam, Netherlands. Elsevier. 2017, pp 687-730. 
